\title{
Article
}

\section{Apolipoprotein E related Co-Morbidities and Alzheimer's disease}

Singhrao, Simarjit Kaur, Harding, Alice, Chukkapalli, Sasanka, Olsen, Ingar, Kesavalu, Lakshmyya and Crean, Stjohn

Available at http://clok.uclan.ac.uk/13305/

Singhrao, Simarjit Kaur ORCID: 0000-0001-9573-5963, Harding, Alice, Chukkapalli, Sasanka, Olsen, Ingar, Kesavalu, Lakshmyya and Crean, Stjohn ORCID: 0000-0001-9336-8549 (2016) Apolipoprotein E related Co-Morbidities and Alzheimer's disease. Journal of Alzheimer's Disease, 51 (4). pp. 935-948. ISSN 1387-2877

It is advisable to refer to the publisher's version if you intend to cite from the work. http://dx.doi.org/10.3233/JAD150690

For more information about UCLan's research in this area go to http://www.uclan.ac.uk/researchgroups/ and search for < name of research Group>.

For information about Research generally at UCLan please go to http://www.uclan.ac.uk/research/

All outputs in CLoK are protected by Intellectual Property Rights law, including Copyright law. Copyright, IPR and Moral Rights for the works on this site are retained by the individual authors and/or other copyright owners. Terms and conditions for use of this material are defined in the policies page.

\section{CLoK}

Central Lancashire online Knowledge www.clok.uclan.ac.uk

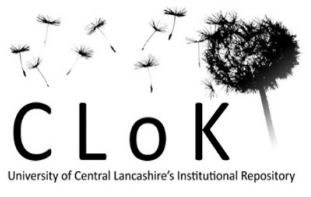




\section{Apolipoprotein E related Co-Morbidities and Alzheimer's disease}

Authors: Sim K. Singhrao ${ }^{1 *}$, Alice Harding ${ }^{1}$, Sasanka Chukkapalli², Ingar Olsen ${ }^{3}$, Lakshmyya Kesavalu ${ }^{2,4^{* *}}$, and StJohn Crean ${ }^{1 * *}$

${ }^{1}$ Oral \& Dental Sciences Research Group, College of Clinical and Biomedical Sciences, School of Dentistry, University of Central Lancashire, Preston, PR1 2HE, UK.

${ }^{2}$ Department of Periodontology, and

${ }^{2,4}$ Department of Oral Biology, College of Dentistry, University of Florida, Gainesville, FA, USA.

${ }^{3}$ Department of Oral Biology, Faculty of Dentistry, University of Oslo, Oslo, Norway.

Running Title: Apoe Co-Morbidities

*Corresponding author: Dr S. K. Singhrao

Tel: +44 (0) 1772895137

Fax: +44 (0) 1772892965

E-mail: $\underline{\text { SKSinghrao@uclan.ac.uk }}$

${ }^{* *}$ Contributed equally. 


\begin{abstract}
The primary goal of advancement in clinical services is to provide a health care system that enhances an individual's quality of life. Incidence of diabetes mellitus, cardiovascular disease and associated dementia coupled with the advancing age of the population, have led to an increase in the worldwide challenge to the healthcare system. In order to overcome these challenges prior knowledge of common, reliable risk factors and their effectors is essential. The oral health constitutes one such relatively unexplored but indispensable risk factor for aforementioned co-morbidities, in the form of poor oral hygiene and tooth loss during aging. Behavioural traits such as low education, smoking, poor diet, neglect of oral health, lack of exercise, and hypertension are few of the risk factors that are shared commonly amongst these conditions. In addition, common genetic susceptibility traits such as the apolipoprotein $\varepsilon$ gene, together with an individual's life style can also influence the development of co-morbidities such as periodontitis, atherosclerosis/stroke, diabetes, and Alzheimer's disease. This review specifically addresses the susceptibility of apolipoprotein $\varepsilon$ gene allele 4 as the plausible commonality for the etiology of co-morbidities that eventually result from periodontal diseases and ultimately progress to dementia.
\end{abstract}

Key words: Co-morbidities, periodontitis, apolipoprotein, dyslipidemia, atherosclerosis, Alzheimer’s disease 


\section{Introduction}

\section{The concept of successful aging}

Successful aging describes optimisation of life expectancy while minimising physical and mental deterioration and disability. Such a state would be characterised by good health; and high levels of independent performance and cognitive functioning [1]. Absence of disease would include chronic diseases such as periodontitis (PD), cardiovascular disease (CVD), type 2 diabetes mellitus (T2DM), and Alzheimer's disease (AD) all of which have an impact on an individual's longevity and quality of life. Even if PD was manifested by an individual, but the disease process was controlled by regular dental prophylaxis, 'successful aging' would still be measured by having retained a greater number of an individual's own teeth [2, 3]. Interestingly, retention of teeth has been positively associated with higher cognitive functioning in the elderly [4]. Further support comes from longevity in the very elderly subjects, referred to as the centenarians, who appear to bypass dementia [5-7] by circumventing other conditions such as diabetes and CVD [8] supporting the potential association of multipleco-morbidities in the development of dementia.

According to the focal infection theory $[9,10]$ the polymicrobial dysbiosis of PD [11] and the subsequent host's immune responses [12] are the pivotal factors that bind the eclectic mix of conditions ranging from the oral condition and T2DM, to inflammatory pathologies including vascular disease(s) and AD. The apolipoprotein gene allele 4 (apoc4) is a susceptibility gene, the inheritance of which not only predisposes individuals to infections [13] that initiate inflammation, but also cause disturbances in their lipid metabolism resulting in dyslipidaemia [14]. However, our own vision of how a risk factor such as an infection may lead to co-morbid states is illustrated in figure 1.

The apos4 has recently been implicated in the aggressive form of periodontitis [15] and in a more aggressive onset of AD [16-18]. Specific microbes such as Aggregatibacter actinomycetemcomitans [A. actinomycetemcomitans] is associated with localised aggressive periodontitis in children and teenagers [19, 20]. The age of onset with plausible genetic factors and the host's immune response predisposing an individual to 
early (aggressive) or late (chronic) onset PD [21. 22] suggests that both forms of periodontitis may eventually become recognised as one disease entity [23].

Thus, apoe4 with an environmental risk factor such as an infection, and/or a fatty diet, combined with smoking and sedentary life style, will likely enhance its biological function in favour of disease outcome. Given that the apoe4 is linked to several diseases such as PD, T2DM, CVD and AD [15-17, 24-28] all of which demonstrate an element of inflammation and dyslipidaemia in their pathogenesis [29-33], further supports the role for infections [25] as a dominant environmental response modifier of disease states. With the growing interest in co-morbid states as well as with the possible association between PD via infections and life style behaviours, it is of interest to explore apoe and its allelic variants further.

\section{Apolipoprotein E}

Apolipoprotein E (apos) is a $34 \mathrm{kDa}$ plasma lipoprotein and its gene is located on the long arm of chromosome 19 (q) at position 13.2 [16, 17]. The protein structure of apoe shows two structural domains [34] which are held together with a hinge region [35] in the three human allelic ( $\varepsilon 2, \varepsilon 3$, and $\varepsilon 4)$ variants [36] figure 2. The proteins of these allelic variants differ by virtue of two amino acid substitutions at the 61 and 112 amino acid positions. For example, $\varepsilon 2$ has cysteines (Cys-61 and Cys-112); $\varepsilon 3$ has Arg-61 and Cys-112 and $\varepsilon 4$ has arginine (Arg-61 and Arg-112) at both positions [34]. The amino acid Cys-112 in both $\varepsilon 2$ and $\varepsilon 3$ preferentially bind high density lipoproteins (HDL) whereas Arg-112 in $\varepsilon 4$ preferentially binds the very low-density lipoprotein (VLDL) lipoproteins [34]. The amino acid change in $\varepsilon 4$ considerably alters its structure with impact on its domain interaction (Fig. 2) and subsequently function in favour of diseases [34, 37, 38] associated with an element of dyslipidaemia in their pathogenesis.

Briefly, dietary fat is converted into fatty acids largely by the various lipase enzymes aiding their digestion [39]. The simplified fatty acids are eventually absorbed by the intestinal mucosa and released into the blood stream in the form of chylomicrons [39]. These plasma lipoproteins based on their relative content of cholesterol and triglycerides are classified into four major classes such as chylomicrons, VLDL, low density 
lipoproteins (LDL) and HDL. Apoe within the blood plasma acts as a form of transport for phospholipids and the nonpolar lipids such as cholesterol and triglycerides to remote body locations. Any surplus lipids are returned to the liver where they undergo several biochemical reactions for either storage as adipose tissue or conversion into vitamin D and appropriate hormones [40]. Any surplus LDL over and above its storage capacity in the blood stream is deemed harmful as it initiates atherosclerosis [41].

Apoe is abundantly synthesized by the hepatocytes in the liver [36] and in the brain, predominantly by astrocytes for local needs [42, 43]. Whilst $\varepsilon 2$ appears to be rarely inherited, it is associated with the genetic disorder known as type III hyperlipoproteinaemia. Apoe3 is the most common isoform found in humans [44] and is considered to be the normal form [38]. Apos4 appears to be associated with the metabolic disorder T2DM [27] and various inflammatory pathologies including aggressive periodontitis [15]; CVD [24, 26]; and $\mathrm{AD}[16,17,25,28]$. Apoc4 may therefore, be interfering with the phenomenon described as 'successful ageing' processes [1] via dyslipidaemia and behavioural traits. The main focus of this review is to envisage the plausible common risk from apos4 in these aforementioned co-morbid states, from periodontitis to AD in relation to oral pathobionts.

\section{Periodontal disease}

PD is a polymicrobial dysbiotic inflammatory disease of the tooth supporting structures, characterised by the destruction of the gingival connective tissue attachment to the root surface and adjacent alveolar bone. Over 700 different bacterial species have been identified in the oral cavity of humans, 400 of these are from the subgingival sulcus [45]. Of the 400 phylotypes of subgingival microbiota, PD involves interaction of specific bacteria; A. actinomycetemcomitans, Porphyromonas gingivalis [P. gingivalis], Treponema denticola [T. denticola $]$ and Tannerella forsythyia $[$ T. forsythia $][11,46]$ and are considered major contributors of human periodontal disease(s) [11, 47].

Disease progression depends on the host's inflammatory and immune responses to the pathogens [12]. As a consequence of host-pathogen interaction, low grade inflammatory mediators are continuously being 
released [48] and these locally breach the periodontal pocket integrity exposing vascular channels to a flow of inflammatory mediator rich sustenance, favourable for the exponential growth of subgingival microflora.

Destruction of host gingival tissues is the consequence of this exposure [49, 50]. Incidence of transient bacteraemia following chewing, tooth brushing and scaling in individuals with periodontal inflammation [51], enabling oral bacteria and bacterial components hematogenous to several systemic organs. Poor oral hygiene, and genetic susceptibility with apoe and low-density lipoprotein receptor-related protein 5 (LRP5) polymorphisms and in the neuropeptide Y (NPY) gene in aggressive periodontitis in the susceptible male host (whereas it is downregulated in female subjects) have been identified suggesting a sex-specific effect of genetic variation of NPY on PD [52]. Genetic polymorphisms would appear to be a risk factor in developing PD, which subsequently associates with remote organ metabolic states such as diabetes [53], and inflammatory pathologies such as vascular disease(s) [54, 55], and AD [56-61], and others that are out of the scope of this review.

Nutrition plays an important role in the development of PD. Poor nutrition, specifically foods high in dietary cholesterol or fatty acids inhibit the immune system [62]. However, it remains unclear whether it is abnormal lipid metabolism or dyslipidaemia that leads to PD or PD leads to impaired lipid metabolism [63]. Dyslipidaemia frequently results from infections that initiate release of inflammatory mediators in the form of cytokines including tumour necrosis factor-alpha (TNF- $\alpha$ ), interleukin-2 (IL-2) and interferon-gamma (IFN- $\gamma$ ) that increase serum triglyceride levels and suppress fatty acid oxidation [14, 64]. Our own vision of how cytokines from periodontal infection in the susceptible host may lead to disturbances in lipid metabolism is illustrated in figure 3.

The case-control study of Gao et al. [15] described four important findings in relation to LRP and dyslipidaemia in the Chinese PD patients. These are; individuals with generalised aggressive periodontitis showed significantly lower total cholesterol and lower HDL than controls; and individuals with LRP5 SNPs (rs682429-AA or rs312016-GG) showed higher total cholesterol, higher HDL and decreased odds for aggressive periodontitis; and individuals with combined polymorphisms (LRP5-rs682429-AA and APOErs429358-CC/CT) had high serum LDL and total cholesterol and decreased odds for aggressive periodontitis; 
and individuals with LRP5 haplotype (rs682429-rs312016:A-G) had decreased odds for aggressive periodontitis.

LRP5 is a co-receptor of the Wnt/ $\beta$-catenin signalling cascade [65] that in health affords protection to the individual from vascular diseases as demonstrated in apoe and LRP5 double gene knockout (ApoE ${ }^{-/-} \mathrm{LRP}^{-/-}$ ) mice [66]. Since LRP5 polymorphisms are also being discovered in aggressive PD, this implies that these polymorphisms are contributing to loss of gene function, and thereby predispose individuals to periodontitis [15]. A plausible mechanism is via association of PD with lower levels of HDL cholesterol, higher levels of both LDL cholesterol and plasma triglycerides [15, 67-69].

Hyperlipidaemia, specifically higher total cholesterol and LDL levels, have been reported with periodontitis experimentally, but epidemiological findings have so far contradicted this finding [69]. As periodontal treatment is known to have a beneficial role on lipid metabolism and supports their intricate association, a plausible confounding factor in Machado et al. [69] study may reflect a mixed population of individuals taking part; who regularly receive dental treatment alongside those who rarely visit the dentist.

\section{Periodontal disease in $\mathrm{ApoE}^{-/-}$mice}

There has been heightened interest in the use of $\mathrm{ApoE}^{-/-}$mice as a model to investigate the association between PD and atherosclerosis and hence it is vital to obtain an understanding of the role of periodontitis and its inflammatory mediators. PD is classically initiated by the colonization/infection of the periodontal pathogens via the oral route, to this end, various researchers have investigated the effects of oral infection of ApoE ${ }^{-/-}$mice with periodontal pathobionts (P. gingivalis, T. denticola, T. forsythia, Fusobacterium nucleatum) [F. nucleatum] [70-73], both as a polymicrobial infection and as monoinfections [71-74]. These studies have demonstrated bacterial colonization and progression of PD in the ApoE $\mathrm{E}^{-/-}$mouse model (bacterial invasion, gingival inflammation, apical migration of junctional epithelium, alveolar bone resorption, and intra-bony defects). By comparing control to infected mice, a significantly elevated IgG response to $P$. gingivalis and $T$. denticola and $T$ forsythia mono-infections as well as in the polymicrobial infections was recorded [70-72]. The 
humoral response generated in all of the infected groups, provides further evidence of a stable response to PD pathogens as well as manifestation of chronic inflammation [70-72]. This primary environmental risk factor (infection) has the potential for pathogenic interplay in the hetero/homozygous apos4 genotype via initiation of an intrinsic cascade of risk factors (infection>inflammation) for dyslipidaemia. Another common feature of all the mono and polyinfected experiments in $\mathrm{ApoE}^{-/-}$mice $[71,75]$ was the abundant expression of NPY gene in vascular tissues [75]. This suggests an intricate relationship of NPY gene and chronic infections with possible manifestation for the development of insulin resistance as discussed below.

\section{Type 2 diabetes mellitus}

Type 2 diabetes mellitus (T2DM) is a metabolic disorder diagnosed in adulthood [76]. It is associated with obesity and is caused by an inefficiency or resistance of the cells to utilise insulin, resulting in a slow but an excess accumulation of sugar in the blood [76]. Insulin resistance reduces glucose tolerance, especially in adipocytes and muscle cells, where the uptake of glucose is insulin dependent. This results in accumulation of glucose in the circulation and a hyperglycaemic state [76], and a homeostatic and systemic imbalance, which is detrimental to health [76]. Increasing evidence supports a bidirectional relationship between T2DM and PD [77]. The hyperglycaemia associated with diabetes results in an increased deposition of advanced glycation end products (AGEs), which bind to neutrophils inhibiting their normal activity [78]. In addition, AGE products activate its receptor (RAGE) which further alters normal macrophage function [78]. These factors subsequently result in an uncontrolled production of proinflammatory cytokines which eventually cause dyslipidaemia as well as increased vascular permeability, collagen fibre break down, destruction of connective tissue, and bone $[78,79]$. This may be another mechanism that increases the risk of the diabetic patient to the development of PD.

The $\varepsilon 4$ variant of apo $\varepsilon$ gene also appears to be associated with T2DM as demonstrated by Alharbi et al., [27] in a Saudi population. The differences between T2DM patients and controls for the homozygous $\varepsilon 4$ [E4/E4: OR, 4.39 (95\% CI: 2.16-8.92); p=0.0001] were shown to be significant. Since patients with this 
hetero/homozygous apoz4 genotype are predisposed to infections [13] generally and to oral pathobionts due to the bi-directional relationship of PD with diabetes [77], a chronic inflammatory (cytokines) state in the insulin resistant patient is likely. In addition, NPY is upregulated following PD infection as demonstrated by Chukkapalli et al. [75] in ApoE ${ }^{-/-}$mice. This is significant as NPY during health modulates a multitude of hypothalamus pituitary adrenal (HPA) axis functions via cortisol release including apatite regulation [80], learning and memory [81, 82], mood [83] and neuroprotection [84]. The HPA axis helps to maintain a sustained stress response if the brain continues to sense that a threat, such as an infection, is present in the body. In response, the hypothalamus secretes corticotropin-releasing hormone, which stimulates the pituitary gland to release adrenocorticotropic hormone, and signals to the adrenal glands to increase the levels of circulating cortisol in the blood. Cortisol helps the body to access the resources needed for a sustained response to threat such as maintaining high levels of blood glucose. The individuals having inherited the heterozygous or

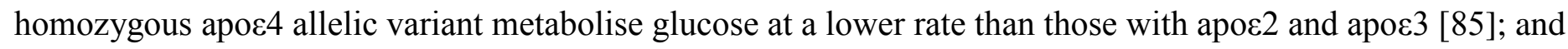
the inflammatory mediators contribute to insulin resistance and disturbance in lipid and glucose metabolism [79]. As a result, the function of various tissues and cells, including adipocytes, hepatocytes, muscle and endothelial cells are affected and impaired, which then leads to other chronic metabolic disease states including obesity, CVD, stroke and AD.

\section{Insulin resistant T2DM in $\mathrm{ApoE}^{-/-}$mice}

$\mathrm{ApoE}^{-/-}$mice have not been used as a model for inducing insulin resistance T2DM. Nevertheless, there is a suggestion of an emerging role of NPY gene that may be of relevance to this metabolic syndrome via its effect on the HPA activity as demonstrated by $\mathrm{ApoE}^{-/-}$mice following an oral infection [75].

\section{Cardiovascular disease}

Cardiovascular disease(s) is characterised by the process of atherosclerosis within blood vessels [86]. It can lead to myocardial infarction, stroke, or peripheral arterial disease according to where it manifests within the 
coronary artery tree, cerebral arteries and/or peripheral arteries [86]. Inflammation and inflammatory processes leading to dyslipidaemia in the vessel wall are major contributors of atherosclerosis [87]. Cardiovascular risk factors show overlapping features with other inflammatory pathologies such as PD and vascular dementias encompassing both lifestyle and genetic factors. These include hypertension, diabetes, dyslipidaemia, smoking and others [88]. The LDL receptor protein mutations and the apoz gene are known genetic susceptibility genes in coronary heart disease $[89,90]$. Patients with poorly controlled PD show high levels of circulating C-reactive protein (CRP) and fibrinogen levels in their serum [91, 92]. Since CRP is a predictor of heart disease, its rise during episodes of poor dental hygiene is currently the strongest link between PD and atherosclerotic vascular disease (ASVD). Translocation of oral pathogens into the main arterial vessels is reported by many investigators using sensitive polymerase chain reaction (PCR) and sequencing alongside the fluorescence in-situ hybridisation (FISH) technique [93-97]. These include $P$. gingivalis and $T$. denticola located within the walls of human coronary artery and atheromatous plaque lesions [93-97]. However these studies remain qualitative as it would take a considerable sample size to determine if there is any statistical significance in these findings.

\section{Experimental periodontitis in $\mathrm{ApoE}^{-/-}$mice initiate systemic disease pathology}

Previous studies have defined the underlying concepts behind the potential causal-association between microbial agents and atherosclerosis, based on the exacerbation of a chronic inflammatory response largely mediated by bacteria. Recent studies exploring the susceptibility of $\mathrm{ApoE}^{-/-}$mice to atheroma formation with mono-infections or as polymicrobial infections demonstrated that oral, metabolically active, pathogens are able to initiate and sustain atherosclerotic lesions in the aorta [70-72, 74, 75, 98]. Furthermore, Hayashi et al. [98] reported that $P$. gingivalis exposure results in an increase of atherosclerotic plaque accumulation in the innominate artery, which is associated with the accumulation of lipids and macrophages closely mimicking the pathology of the human atherosclerosis. 


\section{Alzheimer's disease}

Alzheimer's disease (AD), is a neurodegenerative condition characterised by an irreversible memory deficit. The main neuropathological hallmark proteins are amyloid beta $(\mathrm{A} \beta)$ and the hyperphosphorylated microtubule associated intra-neuronal neurofibrillary tangles (NFTs), both of which are critical to AD post-mortem diagnosis [99]. There are two main forms of $\mathrm{AD}$, the rarer inherited form and the more prevalent, late-onset form. The familial form is characterised by missense mutations in three genes; the amyloid precursor protein (APP), located on chromosome 21, and the presenilin 1 (PSEN 1) and 2 (PSEN 2) genes located on chromosomes 14 and 1 respectively and are all related to enhanced A $\beta$ deposition. Mutations in the tau gene have been identified in familial forms of frontotemporal dementias linked to chromosome 17 [100] but not in AD that are directly attributed with the NFT lesion. For both forms of AD, there are two major but common risk factors namely advancing age and the apoe4 susceptibility gene [16, 17].

Investigating the pathological interactions of mutated genes revealed that the insoluble, fibrillary A $\beta$ plaques are a break down product of the APP gene proteases known as $\alpha, \beta$ and $\gamma$ secretases [101]. These proteases are the translational products of PSEN 1 and 2 genes, and the cleavage sites of their substrate (APP) are well documented by numerous reviews [101-103]. In essence, the $\alpha$ secretase cleavage of APP protein confers little pathogenicity; whereas; depending on the cleavage site of APP protein by the $\beta$ and $\gamma$ secretase enzyme(s), two major species of fibrillary $A \beta_{(40 / 42)}$ are deposited in $A D$ brains. Of these $A \beta_{42}$ is regarded as the pathogenic form due to its association with neuritic plaques, which are composed of degenerating nerve tissues with a tight core made up of $A \beta_{42}$ fibrils [104]. The toxicity of $A \beta_{42}$ fibrils can be explained by their antimicrobial properties [105]. In the brain, $A \beta$ fibrils play a role as immune modulators of the innate immune system potentiating activation of the complement cascade [106]. Since neurons are vulnerable to complement mediated lysis [107], the neurites on the periphery of $A \beta_{42}$ deposits represent debris of dead neurons whilst glia [108] continue, albeit in vain, to synthesize inflammatory components for their clearance.

Despite the generally accepted toxicity of the fibrillary $\mathrm{A} \beta_{42}$, Braak and Braak, [109] questioned its correlation with progressive cognitive decline in AD cases. To this end, researchers examining 
how amyloid fibrils form, led to the simultaneous publication of papers from two laboratories reporting the discovery of 'protofibrils’ [110, 111]. Continued work by others has revealed progressively smaller neurotoxic assemblies known as ‘oligomers’, which appear more toxic than fibrils alone [110-116]. Among these is the soluble form of $A \beta^{*} 56$ which has been shown to be negatively associated with cognitive decline in an APP transgenic mouse model [117] and when injected into the rat brain [118]. Consequently, the original amyloid hypothesis of Hardy and Selkoe [113] has been modified to the 'A $\beta$ oligomer hypothesis' as originally termed by Ono et al. [115]. Since both insoluble A $\beta$ plaques and NFT lesions are essential for the definitive diagnosis of $\mathrm{AD}$, the weakness of the amyloid hypothesis remains in demonstrating the association of $\mathrm{A} \beta$ with many other pathogenic domains of this specific neurodegenerative condition.

The apoc4 has so far emerged as the most significant risk factor for both the familial and late-onset forms of AD associating with almost every pathogenic domain as well as an aggressive disease form with an earlier age of onset $[16,17,119]$. Apoc4 binds $A \beta$ at the $244-272$ residue site (C-terminal residues on apos4) $[17,44]$. It has recently been demonstrated that the N-terminal residues of apo\&4 bind to NFTs [103] highlighting the important role of this protein in both $\mathrm{AD}$ and in the two main pathological lesions (A $\beta$ and NFT’s) thereby gaining support for its association in AD proteostasis. Furthermore, the full length apoe4 is prone to proteolytic cleavage at the C-terminus (methionine 272 or serine 268) that produces a 29 kDa fragment and again at the $\mathrm{N}$-terminal resulting in fragments of $14-20 \mathrm{kDa}$ [38]. The partial proteolytic cleavage of apos4 at the hinge region that holds the two domains together [35] by the yet unidentified proteases has two direct implications in the brain; first the generation of two toxic fragments and second, reduced levels of the whole (apos) protein [38]. The reduced levels of apos4 is unable to maintain adequate lipid homeostasis in the aging brain due to its rapid clearance $[120,121]$ and its decreased binding to A $\beta$ contributes to amyloid accumulation in $\mathrm{AD}[44,122-124]$ possibly resulting as a form of dyslipidaemia.

Infections and inflammation induce dyslipidaemia [14], and AD pathogeneses is not complete without documenting chronic peripheral infections [61]. These include Chlamydophila pneumoniae [C. pneumoniae], T. denticola, $P$. gingivalis which are also found in atheroma plaque tissues [93-97] and in AD brains [56, 60, 125], 
herpes simplex virus type I [126], and several species of spirochetes of which the well cited ones are $T$.

denticola [56] and Borrelia burgdorferi [127]. Although the exact aetiological agent(s) responsible the lateonset $\mathrm{AD}$ (LOAD) remain elusive, spirochetes appear as highly plausible candidates as exemplified by the condition long-standing, stationary or atrophic form of general paresis, which is caused by Treponema pallidum [T. pallidum] infection. The atrophic form of general paresis has recently become accepted as an example of a chronic bacterial infection leading to dementia, reproducing the neuropathological hallmarks of AD [128]. More recent reports relating infections to a causative role in the onset of dementia are supported by Kamer et al. [129] suggesting that mild periodontitis is associated with higher brain amyloid load in normal elderly subjects in the hippocampus.

Dementia can result from infections with AD hallmark proteostatsis [128] and from infection and inflammation alone as exampled by HIV-dementia [130]. The introduction of successful antiretroviral medication has led to people with HIV infection living longer. This is introducing an aging group suffering sustained HIV-associated immune activation and chronic inflammation which is thought to be, at least in part, responsible for the increased comorbid chronic disease that this group experiences. HIV positive subjects show increased prevalence of CVD, hypertension, renal disease, diabetes and osteoporosis compared to controls [131] and develop HIV-dementia [130].

\section{Experimental periodontitis in $\mathrm{ApoE}^{-/-}$mice initiate inflammatory pathology in the brain}

The downstream effects of $P$. gingivalis mono-infection in $\mathrm{ApoE}^{-/-}$mice was recently reported by Poole et al. [132] in which they reported the translocation of this PD pathogen from the oral cavity into the brain tissue likely via the haematogenous route; although other pathways for its translocation are also possible [133]. Examination of the brain tissue highlighted the brains own inflammatory cells (microglia and astrocytes) were activated and neurons were being attacked by excessive complement activation supporting ongoing intracerebral inflammation in the absence of $\mathrm{AD}$ hallmark proteins [132]. For the relevance of finding $P$. gingivalis in the $\mathrm{ApoE}^{-/-}$mice brains, the reader is directed to another review article published elsewhere [134]. 


\section{Apo\&4 as the plausible commonality for the etiology of co-morbidities}

All of the above mentioned conditions share at least one common genetic susceptibility the $\varepsilon 4$ allelic variant, and the common life style and behavioural traits $[15,16,24,27]$. They all show an association with peripheral infections directly or indirectly [11, 31, 56, 60, 135], inflammation [12, 31, 135, 136] and dyslipidaemia [29, 30, 32, 33].

In view of the apparent relationship between successful aging and apoc alleles it was of interest to explore the association between aging and retention of natural teeth [4]. When apoc allele frequencies were analysed and compared between groups of edentulous and dentate human subjects, the edentulous group showed a significantly higher frequency of the apoe4 allele [4]; but the limitations with this study were that it is unknown whether possessing the apoz4 allele made an individual more susceptible to periodontitis specifically, or to disease in general and tooth loss was a consequence of an overall deterioration in health.

Borilova Linhartova et al. [32] investigated the association between PD and the apos4 allele in a casecontrol study using genomic DNA in which they reported that apoc gene variability was not significantly different between the two groups examined (chronic PD sufferers and those without PD); although those with chronic PD demonstrated increased total cholesterol and LDLs compared to controls [32]. In addition, no significant differences were found between groups for triglyceride and HDL levels [32]. Although environmental influences such as smoking, age and gender, socioeconomic factors, obesity, diabetes and family history are known to associate with PD [137-139], the genetic links on the whole, are only now being documented. It is generally recognised that the aggressive forms of PD have a stronger genetic association [15, 22] than the chronic form. However, the research by Gao et al. [15] demonstrated an association between the apos gene and LRP5 polymorphism in the aggressive form of PD, which along with this genetic risk factor strengthens the periodontal association with the emerging cardiovascular and AD pathologies.

Literature supports the presence of groups of individuals who are destined to suffer, as in, familial forms of disease. These can be excluded from those who inherit susceptibility genes. In addition to apos 4 
commonality for the etiology of co-morbidities, there are individuals with other common susceptibility traits for PD. These account for approximately 50\% genetic variance with polymorphisms in inflammatory mediator gene regions such as IL-1, IgG Fc receptor, and TNF- $\alpha$. Polymorphisms in IL-1 $\alpha$, IL-1 $\beta$, IL-6, and TNF- $\alpha$, complement component 1(q subcomponent, A chain) genotypes are reported in periodontitis [140-143]. Additionally, IL-1 $\alpha$, IL-1 $\beta$, IL-6, TNF- $\alpha, \alpha 2$-macroglobulin (also known as LDL receptor related protein or LRP), and alpha1anti-chymotrypsin, complement receptor 1 (CR1) and clusterin are not only all upregulated but also show polymorphic associations in AD cases [144-147] suggesting common inflammatory gene susceptibility profiles in the expression of PD to AD likely contributing to dyslipidaemia. As the susceptibility gene clearly requires an environmental risk factor for the expression of disease, avoidance of risk would be one therapeutic solution. For example, it is documented that not everyone with the hetero/homogeneous inheritance of apos4 will result in manifesting diabetes, vascular diseases and $\mathrm{AD}[8,148]$, and if this risk factor is an oral infection, $(56,60,61)$ as supported by the $\mathrm{ApoE}^{-/-}$mice induced with PD studies $[70-73,75,132]$, then there is a therapeutic window for the related co-morbid states to modify the course of disease by adoption of healthy lifestyles and promotion of awareness about important early warning signs of serious health conditions by regular dental visits.

\section{Acknowledgements}

This review was supported by the NIH National Institute for Dental and Craniofacial Research (R01DE020820;

Dr. Kesavalu). Dr. Olsen acknowledges funding through the European Commission (FP/-Health-306029

“TRIGGER”). The work performed in the UK was fully funded by the University of Central Lancashire.

\section{Conflict of Interests}

The authors declare that there is no conflict of interests regarding the publication of this paper. 


\section{Legends and Figures}

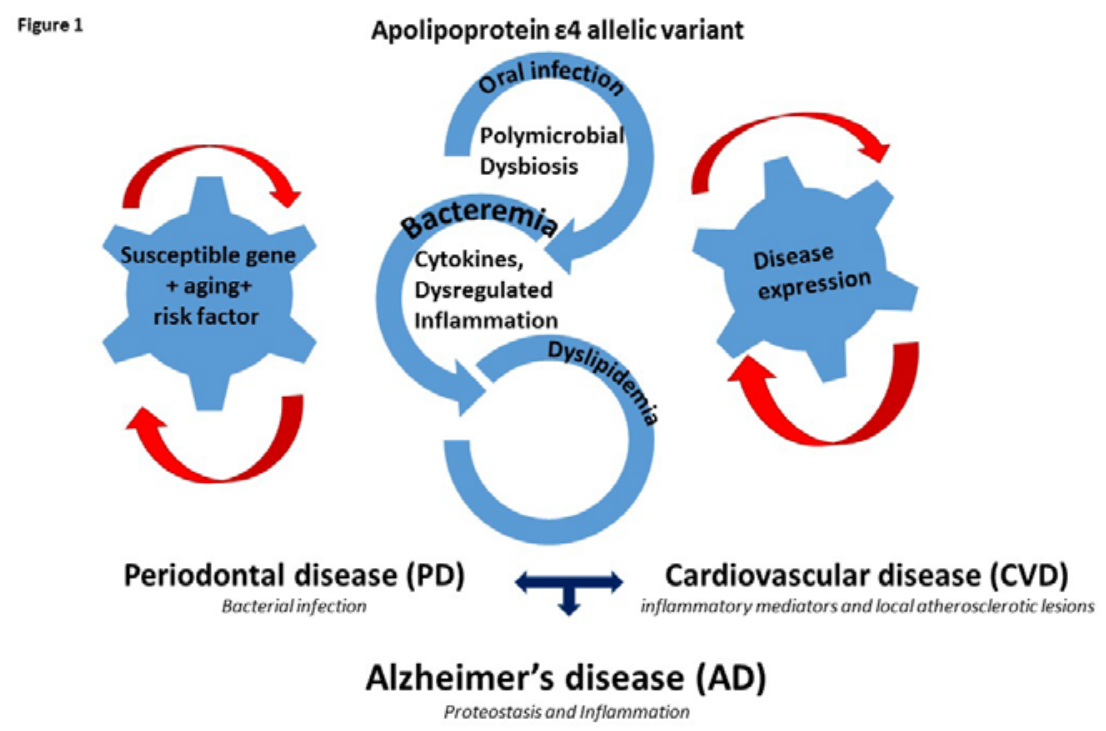

Figure 1. Schematic illustration of the intricate cascade of interaction between apos4 and environmental risk factor such as an oral infection from PD. Following poor oral hygiene the gingivae can bleed and allow access of periodontal bacteria to the systemic circulation where immune cells survey entry of noxious agents. Upon recognizing pathogenic bacteria, these immune cells release inflammatory mediators (cytokines) to combat infection but as the pathobionts have strategies of their own to evade the immune surveillance they remain viable. At the acute phase of infection, disturbances in the lipid metabolism take place in the form of dyslipidaemia. If the lipid imbalance is sustained, during aging, the dyslipidaemia can augment disease pathogenesis including atherosclerosis, cerebrovascular disease and AD. 

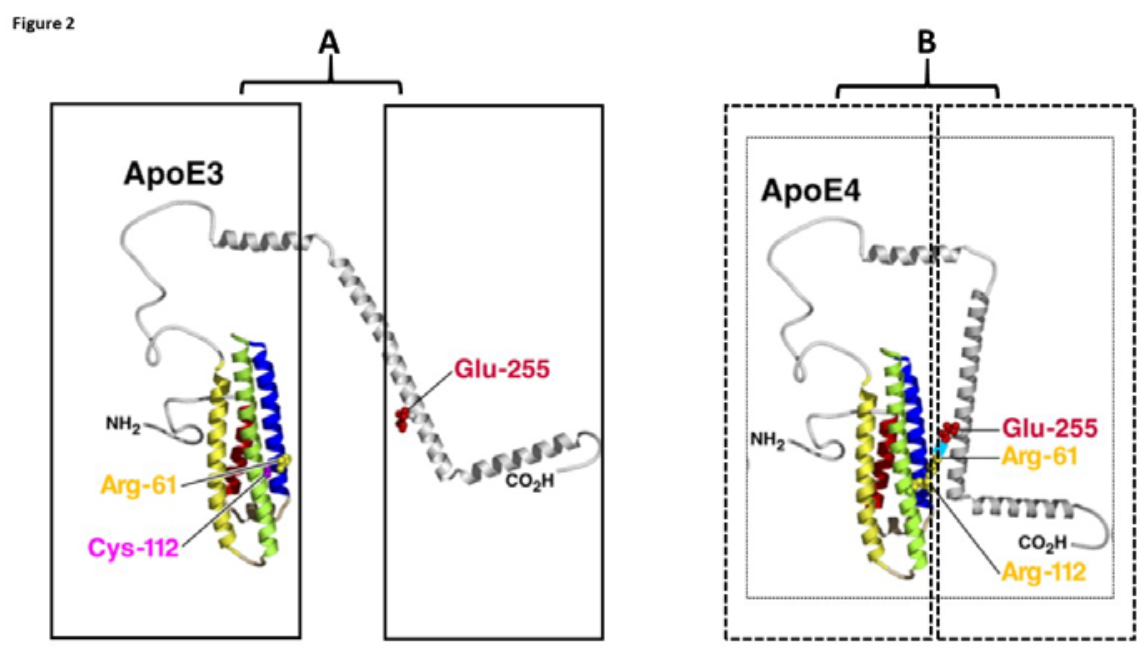

Figure 2. Models of apos3 and apos4 adapted from Mahley and Huang [149]. The rectangular boxes show the differences in the molecule in respect to amino acid changes in the two allelic variants. The space between the two boxes (solid lines) in A is greater than in B (boxes with broken lines) where domain interaction appears restricted.
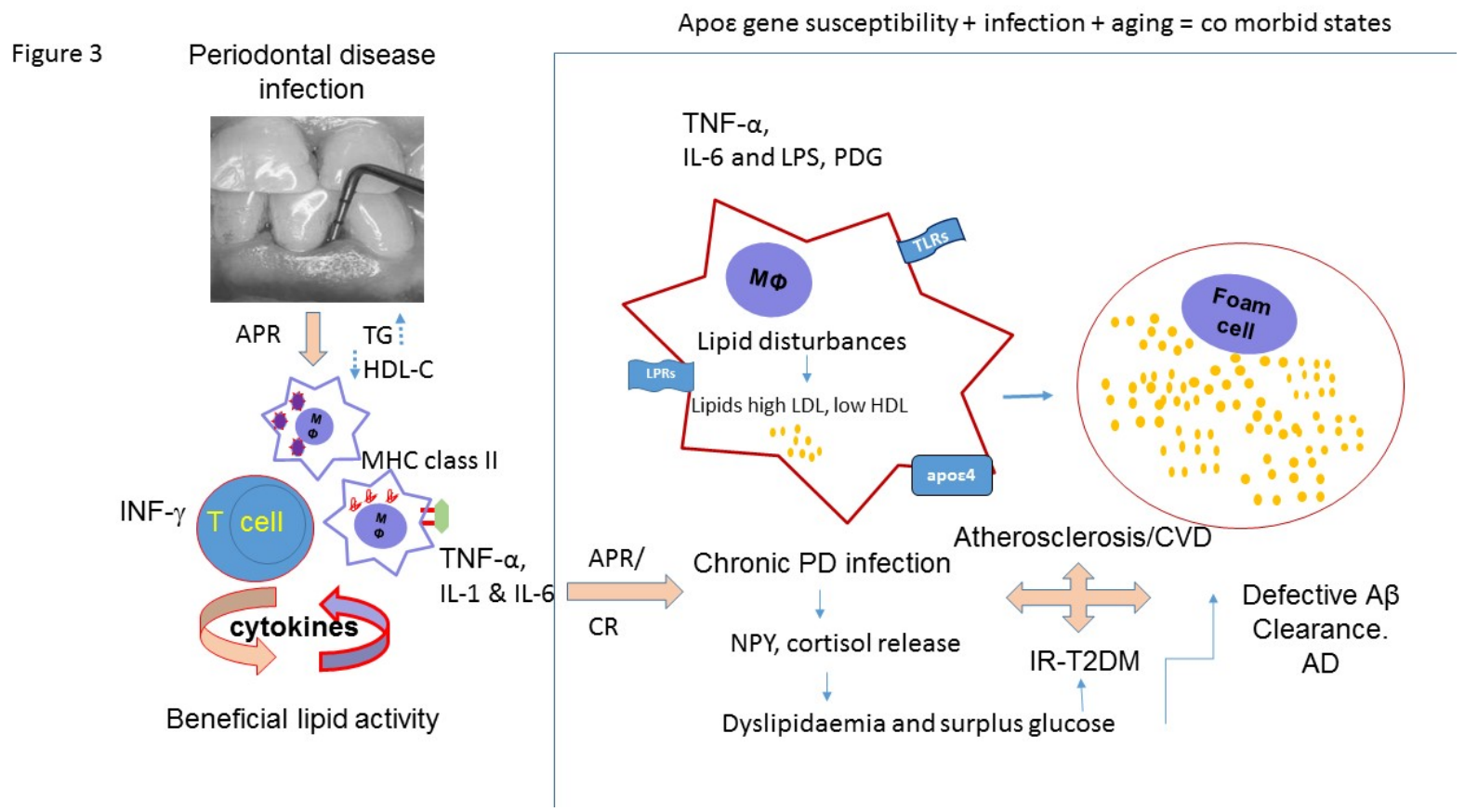

Figure 3. Pictorial illustration of interaction between apos 4 with its infectious risk factor resulting from PD. Following poor oral hygiene, there is local inflammation in the gingivae and in the systemic circulation. The 
blood borne immune cells at both tissue sites and in the systemic channels release inflammatory mediators (cytokines $=$ APC or acute phase response) to prevent spread of infection. At the same time disturbances in the lipid metabolism take place thereby the balance of LDL and cholesterol becomes "tilted" leading to higher HDL (dyslipidaemia). If the lipid imbalance is sustained for longer time, that can augment disease pathogenesis such as atherosclerosis and other co-morbidities. Abbreviations: $\mathrm{TG}=$ triglycerides, $\mathrm{CR}=$ chronic response, $\mathrm{M} \phi=$ macrophage, LPS = lipopolysaccharide, PDG = peptidoglycan, TLRs = toll like receptors, LPRs = low density lipoprotein receptors, NPY = neuropeptide Y, IR = insulin resistant, $\mathrm{A} \beta$ = beta-amyloid. Cytokines (TNF- $\alpha$, IFN- $\gamma$, IL-1 and IL-6) and Lipids (HDL-C, LDL, HDL) and diseases (PD, CVD, T2DM, AD) are abbreviated as in main body text.

\section{References}

[1] Bowling A, Dieppe P (2005) What is successful ageing and who should define it? BMJ 331(7531), 15481551.

[2] Rowe JW, Kahn RL (1987) Human aging: usual and successful. Science 237, 143-149.

[3] Habib R, Nyberg L, Nilsson L-G (2007) Cognitive and non-cognitive factors contributing to the longitudinal identification of successful older adults in the Betula study. Aging Neuropsychol Cogn 14, 257-273.

[4] Bergdahl M, Habib R, Bergdahl J (2007) Natural teeth and cognitive function in humans. Scand J Psychol 48, $557-565$.

[5] Hitt R, Young-Xu Y, Silver M, Perls T (1999) Centenarians: the older you get the healthier you've been. Lancet 354, 652.

[6] Kliegel M, Moor C, Rott C (2004) "Cognitive status and development in the oldest old: a longitudinal analysis from the Heidelberg Centenarian study”. Arch Gerontol Geriatr 39(2), 143-156.

[7] Perls T (2004) Centenarians who avoid dementia. Trends Neurosci 27(10), 633-636.

[8] Imhof A, Kövari E, von Gunten A, Gold G, Rivara CB, Herrmann FR, Hof PR, Bouras C, Giannakopoulos P (2007) Morphological substrates of cognitive decline in nonagenarians and centenarians: A new paradigm? $J$ Neurool Sci 257, 72-79.

[9] Miller WD (1891) The human mouth as a focus of infection. Dent Cosmos 33, 689-713.

[10] Hunter WD (1900) Oral sepsis as a cause of disease. BMJ 2, 215-216. 
[11] Socransky SS, Haffajee AD, Cugini MA, Smith C, Kent RL (1998) Microbial complexes in subgingival plaque. J Clin Periodontol 25(2), 134-144.

[12] Haffajee AD, Socransky SS, Dzink JL, Taubman MA, Ebersole JL, Smith DJ (1988) Clinical, microbiological and immunological features of subjects with destructive periodontal diseases. J Clin Periodontol 15, 240-246.

[13] Burt TD, Agan BK, Marconi VC, He W, Kulkarni H, Mold JE, Cavrois M, Huang Y, Mahley RW, Dolan MJ, McCune JM, Ahuja SK (2008) Apolipoprotein (apo) E4 enhances HIV-1 cell entry in vitro, and the APOE ¿4/ ع4 genotype accelerates HIV disease progression. Proc Natl Acad Sci USA 105, 8718-8723.

[14] Khovidhunkit W, Kim MS, Memon RA, Shigenaga JK, Moser AH, Feingold KR, Grunfield C (2004) Effects of infection and inflammation on lipid and lipoprotein metabolism: mechanisms and consequences to the host. J Lipid Res 45, 1169-1196.

[15] Gao H, Tian Y, Meng H, Hou J, Xu L, Zhang L, Shi D, Lu R, Feng X, Wang X, Chen Z (2015) associations of apolipoprotein $\mathrm{E}$ and low-density lipoprotein receptor-related protein 5 polymorphisms with dyslipidemia and generalized aggressive periodontitis in a Chinese population. J Periodontal Res 50, 509-518. [16] Corder EH, Saunders AM, Strittmatter WJ, Schmechel DE, Gaskell PC, Small GW, Roses AD, Haines JL, Pericak-Vance MA (1993) Gene dose of apolipoprotein E type 4 allele and the risk of Alzheimer's disease in late onset families. Science 261, 921-923.

[17] Saunders AM, Strittmatter WJ, Schmechel D, George-Hyslop PH, Pericak-Vance MA, Joo SH, Rosi BL, Gusella JF, Crapper-MacLachlan DR, Alberts MJ, et al. (1993) Association of apolipoprotein E allele epsilon 4 with late-onset familial and sporadic Alzheimer's disease. Neurol 43(8), 1467-1472.

[18] Roses AD (1996) Apolipoprotein E alleles as risk factors in Alzheimer’s disease. Annu Rev Med 47, 387400.

[19] Armitage GC (2004) Periodontal diagnoses and classification of periodontal diseases. Periodontology 2000 34, 9-21.

[20] Armitage, GC (2010) Comparison of the microbiological features of chronic and aggressive periodontitis. Periodontology 2000 53, 70-88.

[21] Michalowicz BS, Diel SR, Gunsolley JC, Sparks BS, Brooks CN, Koertge TE, Califano JV, Burmester JA, Schenkein HA (2000) Evidence of substantial genetic basis for risk of adult periodontitis. J Periodontol 84, 1699-1707.

[22] Maney P, Owens JL (2015) Interleukin polymorphisms in aggressive periodontitis: A literature review. J Indian Soc Peridontol 19(2), 131-41.

[23] Armitage G, Cullinan MP (2010) Comparison of the clinical features of chronic and aggressive periodontitis. Periodontology 2000 53, 12-27.

[24] Wilson PW, Myers RH, Larson MG, Ordovas JM, Wolf PA, Schaefer EJ (1994) Apolipoprotein E alleles, dyslipidemia, and coronary heart disease. The Framingham Offspring Study. JAMA 272, 1666-1671.

[25] Farrer LA, Cupples LA, Haines JL, Hyman B, Kukull WA, Mayeux R, Myers RH, PericaK-Vance MA, Risch N, van Duijin CM (1997) Effects of age, sex, and ethnicity on the association between apolipoprotein E 
genotype and Alzheimer disease. A meta-analysis. APOE and Alzheimer Disease Meta Analysis Consortium. JAMA 278, 1349-1356.

[26] Kolovou GD, Anagnostopoulou KK (2007) Apolipoprotein E polymorphism, age and coronary heart disease. Ageing Res Rev 6, 94-108.

[27] Alharbi KK, Khan IA, Syed R (2014) Association of apoliporprotein E polymorphisms with type 2 diabetes mellitus in a Saudi population. DNA Cell Biol 33(9), 637-641.

[28] Huang Y, Mahley RW (2014) Apolipoprotein E: Structure and function in lipid metabolism, neurobiology and Alzheimer's diseases. Neurobiol Dis 72, 3-12.

[29] DeFronzo RA, Ferrannini E (1991) Insulin resistance. A multifaceted syndrome responsible for NIDDM, obesity, hypertension, dyslipidemia and atherosclerotic cardiovascular disease. Diabetes Care 14, $173-194$.

[30] Mooradian AD (2009) Dyslipidaemia in type 2 diabetes mellitus. Nat Clin Pract Endocrinol Metab 5(3), 150-9. doi: 10.1038/ncpendmet1066.

[31] Gan YH (2013) Host susceptibility factors to bacterial infections in type 2 diabetes. PLoS Pathog 9(12), e1003794. doi: 10.1371/journal.ppat.1003794.

[32] Borilova Linhartova P, Bartova J, Poskerova H, Machal J, Vokurka J, Fassman A, Izakovicova Holla L (2015) Apolipoprotein E gene polymorphisms in relation to chronic periodontitis, periodontopathic bacteria and lipid levels. Arch Oral Biol 60(3), 456-462.

[33] Duarte JH (2015) Genetics: Alzheimer disease and dyslipidaemia. Nat Rev Cardiol 12(6), 318. doi: 10.1038/nrcardio.2015.67.

[34] Weisgraber KH, Mahley RW (1996) Human apolipoprotein E: the Alzheimer’s disease connection. FASEB $J$ 10, 1485-1494.

[35] Wetterau JR, Aggerbeck LP, Rall SC, Weisgraber KH (1988) Human apolipoprotein E3 in aqueous solution. I. Evidence for two structural domains. J Biol Chem 263, 6240-6248.

[36] Mahley RW (1988) Apolipoprotein E: cholesterol transport protein with expanding role in cell biology. Science 240, 622-630.

[37] Mahley RW, Weisgraber KH, Huang Y (2006) Apoliporprotein E4: a causative factor and therapeutic target in neuropathology, including Alzheimer's disease. Proc Natl Acad Sci USA 103(15), 5644-5651.

[38] Mahley RW, Huang Y (2012) Apolipoprotein E sets the stage: Response to injury triggers neuropathology. Neuron 76(5), 871-885.

[39] Iqbal J, Hussain MM (2009) Intestinal lipid absorption. Am J Physiol Endocrinol Metab 296(6), E1183E1194.

[40] Hu J, Zhang Z, Shen WJ, Azhar S (2010) Cellular cholesterol delivery, intracellular processing and utilization for biosynthesis of steroid hormones. Nutr Metab (Lond) 7, 47. doi: 10.1186/1743-7075-7-47. 
[41] Berliner JA, Navab M, Fogelman AM, Frank JS, Demer LL, Edwards PA, Watson AD, Lusis AJ (1995) Atherosclerosis: basic mechanisms. Oxidation, inflammation, and genetics. Circulation 91, 2488-2496.

[42] Pitas RE, Boyles JK, Lee SH, Foss D, Mahley RW (1987) Astrocytes synthesize apolipoprotein E and metabolize apolipoprotein E-containing lipoproteins. Biochem Biophys Acta 917, 148-161.

[43] Grehan S, TSE E, Taylor JM (2001) Two distal downstream enhancers direct expression of the human apolipoprotein E gene to astrocytes in the brain. J Neurosci 21, 812-822.

[44] Strittmatter WJ, Weisgraber KH, Huang DY, Dong L, Salvesen GS, Pericak-Vance M, Schmechel D, Saunders AM, Goldgaber D, Roses AD (1993) Binding of human apolipoprotein E to synthetic amyloid ßpeptide: Isoform-specific effects and implications for late-onset Alzheimer's disease. Proc Natl Acad Sci USA 90, 8098-8102.

[45] Leszcynska A, Buczko P, Buczko W, Pietruska M (2011) Periodontal pharmacology - an updated review. Adv Med Sci 56, 123-131.

[46] Kamer AR, Craig RG, Dasanayake AP, Brys M, Glodzik-Sobanska L, de Leon MJ (2008) Inflammation and Alzheimer's disease: Possible role of periodontal diseases Alzheimers Dement 4(4), 242-250.

[47] Holt SC, Ebersole JL (2005) Porphyromonas gingivalis, Treponema denticola and Tannerella forsythia: the "red complex", a prototype polybacterial pathogenic consortium in periodontitis. Periodontol 2000 38:72122.

[48] Moutsopoulos NM, Madianos PN (2006) Low-grade inflammation in chronic infectious diseases: paradigm of periodontal infections. Ann NY Acad Sci 1088, 251-264.

[49] Hajishengalis G (2010) Complement and periodontitis. Biochem Pharmacol 80(12), 1992-2001.

[50] Hajishengalis G, Abe T, Maekawa T, Hajishengalis E, Lambris JD (2013) Role of complement in hostmicrobe homeostasis of the periodontium. Semin Immunol 25(1), 65-72.

[51] Forner L, Larsen T, Kilian M, Holmstrup P (2006) Incidence of bacteremia after chewing, tooth brushing and scaling in individuals with periodontal inflammation. J Clin Periodontol 33(6), 401-407.

[52] Freitag-Wolf S, Dommisch H, Graetz C, Jockel-Schneider Y, Harks I, Staufenbiel I, Meyle J, Eickholz P, Noack B, Bruckmann C, Gieger C, Jepsen S, Lieb W, Schreiber S, Konig IR, Schaefer AS (2014) Genome-wide exploration identifies sex-specific genetic effects of alleles upstream NPY to increase the risk of severe periodontitis in men. $J$ Clin Periodontol 41, 1115-11121.

[53] Grossi SG, Genco RJ (1998) Periodontal disease and diabetes mellitus: a two-way relationship. Ann Periodontol 3, 51-61.

[54] DeStefano F, Anda RF, Kahn HS, Williamson DF, Russell CM (1993) Dental disease and risk of coronary heart disease and mortality. BMJ 306(6879), 688-691.

[55] Scannapieco FA, Bush RB, Paju S (2003) Associations between periodontal disease and risk for atherosclerosis, cardiovascular disease, and stroke. A systematic review. Annals Periodontal. 8, 38-53.

[56] Riviere GR, Riviere K, Smith K (2002) Molecular and immunological evidence of oral Treponema in the human brain and their association with Alzheimer's disease. Oral Microbiol Immunol 17(2), 113-118. 
[57] Stein PS, Desrosiers M, Donegan SJ, Yepes JF, Kryscio RJ (2007) Tooth loss, dementia and neuropathology in the Nun Study. J Am Dent Assoc 138(10), 1314-1322.

[58] Kamer AR, Craig RG, Pirraglia E, Dasanayake AP, Norman RG, Boylan RJ, Nehorayoff A, Glodzik L, Brys M, de Leon MJ (2009) TNF-alpha and antibodies to periodontal bacteria discriminate between Alzheimer's disease patients and normal subjects. J Neuroimmunol 216(1-2), 92-97.

[59] Noble JM, Borrell LN, Papapanou PN, Elkind M, Scarmeas N, Wright C (2009) Periodontitis is associated with cognitive impairment among older adults: analysis of NHANES-lll. J Neurol Neurosurg Psychiatry (11), 1206-1211.

[60] Poole S, Singhrao SK, Kesavalu L, Curtis MA, Crean S (2013) Determining the presence of periodontopathic virulence factors in short-term postmortem Alzheimer's disease brain tissue. $J$ Alzheimers Dis 36(4), 665-677.

[61] Olsen I, Singhrao SK (2015) Can oral infection be a risk factor for Alzheimer's disease? J Oral Microbiol 7, 29143. doi.org/10.3402/jom.v7.29143.

[62] Marti A, Marcos A, Martinez JA (2001) Obesity and immune function relationships. Obes Rev 2(2), 131140 .

[63] Saito T, Shimazaki Y (2007) Metabolic disorders related to obesity and periodontal disease disorders Periodontol 2000 43, 254-266.

[64] Hardardottir I, Grunfeld C, Feingold KR (1994) Effects of endotoxin and cytokines on lipid metabolism. Curr Opin Lipidol 5, 207-215.

[65] Joiner DM, Ke J, Zhong Z, Xu HE, Williams Bo (2013) LRP5 and LRP6 in development and disease. Trends Endocrinol Metab 24(1), 31-39.

[66] Borrell-Pages M, Romero JC, Badimon L (2015) LRP5 deficiency down-regulates Wnt signalling and promotes aortic lipid infiltration in hypercholesterolaemic mice. J Cell Mol Med 19(4), 770-777.

[67] Cutler CW, Shinedling EA, Nunn M, Jotwani R, Kim B, Nares S, Lacopino AM (1999) Association between periodontitis and hyperlipidaemia: cause or effect? J Periodontol 70, 1429-1434.

[68] Katz J, Flugelman MY, Goldberg A, Heft M (2002) Association between periodontal pockets and elevated cholesterol and low density lipoprotein cholesterol levels. J Periodontol 73, 494-500.

[69] Machado AC, Quirino MR, Nascimento LF (2005) Relation between chronic periodontal disease and plasmatic levels of triglycerides, total cholesterol and fractions. Braz Oral Res 19, 284-289.

[70] Rivera MF, Lee J-Y, Aneja M, Goswami V, Liu L, Velsko IM, Chukkapalli SS, Bhattacharyya I, Chen H, Lucas AR, Kesavalu L. (2013) Polymicrobial infection with major periodontal pathogens induced periodontal disease and aortic atherosclerosis in hyperlipidemic APOE null mice. PLOS One 8(2), e57178.

[71] Velsko IM, Chukkapalli SS, Rivera MF, Lee J-Y, Chen H, Zheng D, Bhattacharyya I, Gangula PR, Lucas AR, Kesavalu L (2014) Active invasion of oral and aortic tissues by Porphyromonas gingivalis in mice causally links periodontitis and atherosclerosis. PLOS One 9(5), e97811. 
[72] Chukkapalli SS, Rivera MF, Velsko IM, Lee J-Y, Chen H, Zheng D, Bhattacharyya I, Gangula PR, Lucas AR, Kesavalu L (2014) Invasion of oral and aortic tissues by oral spirochete Treponema denticola in APOE mice causally links periodontal disease and atherosclerosis. Infect Immun 82(5), 1959-1967.

[73] Chukkapalli SS, Rivera-Kweh MF, Velsko IM, Chen H, Zheng D, Bhattacharyya I, Gangula PR, Lucas AR Kesavalu L (2015) Chronic oral infection with major periodontal bacteria Tannerella forsythia modulates systemic atherosclerosis risk factors and inflammatory markers. Pathog Dis 73, ftv009. doi:

10.1093/femspd/ftv009.

[74] Lalla E, Lamster IB, Hofmann MA, Bucciarelli L, Jerud AP, Tucker S, Lu Y, Papapanou PN, Schmidt AM (2003) Oral infection with a periodontal pathogen accelerates early atherosclerosis in apolipoprotein E-null mice. Arterioscler Thromb Vasc Biol 23, 1405-1411.

[75] Chukkapalli SS, Velsko IM, Rivera-Kweh MF, Zheng D, Lucas AR, Kesavalu L (2015) Polymicrobial oral infection with four periodontal bacteria orchestrates a distinct inflammatory response and atherosclerosis in ApoEnull mice. PLoS One 10(11), e0143291. doi: 10.1371/journal.pone.0143291.

[76] Barbieri J, Fontela PC, Winkelmann ER, Zimmerman CEP, Sandri YP, Mallet EKV, Frizzo MN (2015) Anemia in patients with type 2 diabetes mellitus; Anemia 2015, doi: 10.1155/2015/354737.

[77] Papapanou PN (1996) Periodontal diseases: Epidemiology. Ann Periodontol 1, 1-36.

[78] Nagpal SJ, Lopez R, Feldstein AE, Alkhouri N (2015) Serum cytokeratin-18 fragment levels predict development of type 2 diabetes mellitus in adult patients with NAFLD. Liver Int May 4, doi: 10.1111/liv.12862.

[79] Pizzo G, Guiglia R, Lo Russo L, Campisi G (2010) Dentistry and internal medicine: from the focal infection theory to the periodontal medicine concept. Eur J Intern Med 21(6), 496-502.

[80] Epel E, Lapidus R, McEwen B, Brownell K (2001) Stress may add bite to appetite in women: a laboratory study of stress-induced cortisol and eating behavior. Psychoneuroendocrinology 26(1), 37-49.

[81] Buchanan TW, Lovallo WR (2001). Enhanced memory for emotional material following stress-level cortisol treatment in humans. Psychoneuroendocrinology 26(3), 307-317.

[82] Het S, Ramlow G, Wolf OT (2005). A meta-analytic review of the effects of acute cortisol administration on human memory. Psychoneuroendocrinology 30(8), 771-784.

[83] Young AH (2004) Cortisol in mood disorders. Stress 7(4), 205-208.

[84] Heiduschka P, Thanos S (2006) Cortisol promotes survival and regeneration of axotomised retinal ganglion cells and enhances effects of aurintricarboxylic acid. Graefes Arch Clin Exp Opthalmol 244, 1512-1521.

[85] Small GW, Ercoli LM, Silverman DH, Huang SC, Komo S, Bookheimer SY, Lavretsky H, Miller K, Siddarth P, Rasgon NL, Mazziota JC, Saxena S, Wu HM, Mega MS, Cummings JL, Saunders AM, Pericakvance MA, Roses AD, Barrio JR, Phelps ME (2000) Cerebral metabolic and cognitive decline in persons at genetic risk for Alzheimer’s disease. Proc Natl Acad Sci USA 106, 14745-14750. 
[86] Schuett KA, Lehrke M, Marx N, Burgmaier M (2015) High-risk cardiovascular patients: clinical features, comorbidities, and interconnecting mechanisms. Front Immunol 6:591, doi: 10.3389/fimmu. 2015.00591.

[87] Libby P, Ridker PM, Maseri A (2002) Inflammation and atherosclerosis. Circulation 105, 1135-1143.

[88] Helfand M, Buckley DI, Freeman M, Fu R, Rogers K, Fleming C (2009) Emerging risk factors for coronary heart disease: a summary of systematic reviews conducted for the U.S. Preventive Services Task Force. Ann Intern Med 151: 496-507.

[89] Brown MS, Goldstein JL (1976) Familial hypercholesterolemia: A genetic defect in the low-density lipoprotein receptor. $N$ Engl J Med 294, 1386-1390.

[90] Curtiss LK, Boisvert WA (2000) Apolipoprotein E and atherosclerosis. Curr Opin Lipidol 21, 167-176.

[91] De Oliveira C, Watt R, Hamer M (2010) Tooth brushing, inflammation, and risk of cardiovascular disease: results from Scottish Health Survey. BMJ 340, c2451.

[92] Genco RJ, Van Dyke TE (2010) Prevention: Reducing the risk of CVD in patients with periodontitis. Nat Rev Cardiol 7(9), 479-480.

[93] Chiu, B (1999) Multiple infections in carotid atherosclerotic plaques Am Heart J 138(5), S534-S536.

[94] Haraszthy V, Zambon J, Trevisan M, Zeid M, Genco R (2000) Identification of periodontal pathogens in atheromatous plaques $J$ Periodontol 71(10), 1554-1560.

[95] Okuda K, Ishihara K, Nakagawa T, Hirayama A, Inayama Y, Okuda K (2001) Detection of Treponema denticola in atherosclerotic lesions. J Clin Microbiol 39, 1114-1117.

[96] Kozarov E, Dorn VBR, Shelburne CE, Dunn WA, Progulske-Fox A (2005) Human atherosclerotic plaque contains viable Actinobacillus actinomycetemcomitans and Porphyromonas gingivalis. Arterioscler Thromb Casc Biol 3, 17-18.

[97] Cavrini F, Sabri V, Moter A, Servidio D, Marangoni A, Montebugnoli L, Foschi F, Prati C, Di Bartolomeo $\mathrm{R}$, Cevenini R (2005) Molecular detection of Treponema denticola and Porphyromonas gingivalis in carotid and aortic atheromatous plaques by FISH: report of two cases J Med Microbiol 54(1), 93-96.

[98] Hayashi C, Viereck J, Hua N, Phinikaridou A, Madrigal AG, Gibson III FC, Hamilton JA, Genco CA (2011) Porphyromonas gingivalis accelerates inflammatory atherosclerosis in the innominate artery of ApoE deficient mice. Atherosclerosis 215, 52-59.

[99] Braak H, Braak E (1995) Staging of Alzheimer's disease related neurofibrillary changes. Neurobiol Aging 16, 271-278.

[100] Foster NL, Wilhelmsen K, Sima AA, Jones MZ, D’Amato CJ, Gilman S (1997) Frontotemporal dementia and parkinsonism linked to chromosome 17: a consensus conference. Conference Participants. Ann Neurol 41, 706-715. 
[101] O’Brien RJ, Wong PC (2011) Amyloid precursor protein processing and Alzheimer’s disease. Annu Rev Neurosci 34, 185-204.

[102] Hutton M, Hardy J (1997) The presenilins and Alzheimer’s disease. Hum Mol Genet 6(10), 1639-1646.

[103] Rohn TT (2013) Proteolytic cleavage of apolipoprotein E4 as the keystone for the heightened risk associated with Alzheimer’s disease. Int J Mol Sci 14, 14908-14922.

[104] Cole G, Neal JW, Singhrao SK, Jasani B, Newman GR (1993) The distribution of amyloid plaques in the cerebellum and brainstem in Down's syndrome and Alzheimer's disease: a light microscopical analysis. Acta Neuopathologica 85, 542-552.

[105] Soscia SJ, Kirby JE, Washicosky KJ, Tucker SM, Ingelsson M, Hyman B, Burton MA, Goldstein LE, Duong S, Tanzi RE, Moir RD (2010) The Alzheimer's disease-associated amyloid beta-protein is an antimicrobial peptide. PLoS One 5(3), e9505. doi: 10.1371/journal.pone.0009505.

[106] Rogers J, Cooper NR, Webster S, Schultz J, McGeer PL, Styren SD, Civin WH, Brachova L, Bradt B, Ward P (1992) Complement activation by beta-amyloid in Alzheimer disease. Proc Natl Acad Sci USA 89(21), 10016-10020.

[107] Singhrao SK, Neal JW, Rushmere NK, Morgan BP, Gasque P (2000) Spontaneous classical pathway activation and deficiency of membrane regulators render human neurons susceptible to complement lysis. Am $J$ Pathol 157, 905-918.

[108] Singhrao SK, Neal JW, Morgan BP, Gasque P (1999) Increased complement biosynthesis by microglia and complement activation on neurons in Huntington’s disease. Exp Neurol 159, 362-376.

[109] Braak H, Braak E (1998) Argyrophilic grain disease: Frequency of occurrence in different age categories and neuropathological diagnostic criteria. J Neural Trans 105, 801-819.

[110] Walsh DM, Lomarkin A, Benedek GB, Condron MM, Teplow DB (1997) Amyloid beta-protein fibrillogenesis. Detection of a protofibrillar intermediate. J Biol Chem 272, 22364-22372.

[111] Harper JD, Wong SS, Lieber CM, Lansbury PT (1997) Observation of metastable Abeta amyloid protofibrils by atomic force microscopy. Chem Biol 4, 119-125.

[112] Klein WL, Krafft GA, Finch CE (2001) Targeting small Abeta oligomers: the solution to an Alzheimer's disease conundrum? Trends Neurosci 24, 219-224.

[113] Hardy J, Selkoe DJ (2002) The amyloid hypothesis of Alzheimer's disease: progress and problems on the road to therapeutics. Science 297, 353-356.

[114] Walsh DM, Selkoe DJ (2004) Oligomers on the brain: the emerging role of soluble protein aggregates in neurodegeneration. Protein Pept Lett 19, 2839-2846.

[115] Ono K, Condron MM, Teplow DB (2009) Structure-neurotoxicity relationships of amyloid beta-protein oligomers. Proc Natl Acad Sci USA 106, 14745-14750.

[116] Hayden EY, Teplow DB (2013) Amyloid $\beta$-protein oligomers and Alzheimer's disease. Alzheimers Res Ther 5(6): 60 . 
[117] Lesne S, Koh MT, Kotilinek L, Kayed R, Glabe CG, Yang A, Gallagher M, Ashe KH (2006) A specific amyloid-beta protein assembly in the brain impairs memory. Nature 440(7082), 352-357.

[118] Poling A, Morgan-Paisley K, Panos JJ, Kim EM, O’Hare E, Cleary JP, Lesne S, Ashe KH, Porrit M, Baker LE (2008) Oligomers of the amyloid-beta protein disrupt working memory: confirmation with two behavioural procedures. Behav Brain Res 193(2), 230-234.

[119] Roses AD (2006) On the discovery of the genetic association of apolipoprotein E genotypes and common late-onset Alzheimer disease. J Alzheimers Dis 9, 361-366.

[120] Poirier J (1994) Apolipoprotein E in animal models of CNS injury and in Alzheimer's disease. Trends Neurosci 17:525-530.

[121] Sullivan PM, Han B, Liu F, Mace BE, Ervin JF, Wu S, Koger D, Paul S, Bales KR(2011) Reduced levels of human apoE4 protein in an animal model of cognitive impairment. Neurobiol Aging 32(5),791-801.

[122] Strittmatter WJ, Saunders AM, Goedert M et al. (19940 Isoform-specific interactions of apolipoprotein E with microtubule-associated protein tau: implications for Alzheimer disease. Proc Natl Acad Sci USA 91, 11183-11186.

[123] Bu G (2009) Apolipoprotein E and its receptors in Alzheimer's disease: pathways, pathogenesis and therapy. Nat Rev Neurosci 10, 333-344.

[124] Hudry E, Dashkoff J, Roe AD, Takeda S, Koffie RM, Hashimoto T, Scheel M, Spires-Jones T, ArbelOrnath M, Betensky R, Davidson BL, Hyman BT (2013) Gene transfer of human Apoe isoforms results in differential modulation of amyloid deposition and neurotoxicity in mouse brain. Sci Transl Med 5:212ra161.

[125] Balin B, Little C, Hammond C, Appelt D, Whittum-Hudson J, Gerard H, Hudson A (2008) Chlamydophila pneumoniae and the etiology of late-onset Alzheimer's disease. J Alzheimers Dis 13, 371-380.

[126] Itzhaki R, Wozniak M (2008) Herpes simplex virus type 1 in Alzheimer's disease: the enemy within. $J$ Alzheimers Dis 13(4), 393-405.

[127] Miklossy J (2008) Chronic inflammation and amyloidogenesis in Alzheimer's disease - role of spirochetes. J Alzheimer Dis 13, 381-391.

[128] Miklossy J (2015) Historic evidence to support a causal relationship between spirochetal infections and Alzheimer's disease. Front Aging Neurosci 7, 46. doi: 10.3389/fnagi.2015.00046.

[129] Kamer AR, Pirraglia E, Tsui W, Rusinek H, Vallabhajosula S, Mosconi L, Yi L, McHugh P, Craig RG, Svetcov S, Linker R, Shi C, Glodzik L, Williams S, Corby P, Saxena D, deLeon MJ (2015) Periodontal disease associates with higher brain amyloid load in normal elderly. Neurobiol Aging 36, 627-633. doi:

10.1016/j.neurobiolaging.2014.10.038.

[130] Watkins CC, Treisman GJ (2015) Cognitive impairment in patients with AIDS - prevalence and severity. HIV AIDS (Auckl) 7, 35-47.

[131] Smit M, Brinkman K, Geerlings S, Smit C, Thyagarajan K, Sighem Av De Wolf F, Hallett TB; ATHENA observational cohort (2015) Future challenges for clinical care of an ageing population infected with HIV: a modelling study. Lancet Infect Dis 15(7), 810-818. 
[132] Poole S, Singhrao SK, Chukkapalli S, Rivera M, Velsko I, Kesavalu L, Crean StJ (2015) Active invasion of an oral bacterium and infection-induced complement activation in ApoE ${ }^{\text {null }}$ mice brains. J Alzheimers Dis 43, 67-80.

[133] Singhrao SK, Harding A, Simmons T, Robinson S, Kesavalu L, Crean S (2014) Oral inflammation, tooth loss, risk factors, and association with progression of Alzheimer's disease. J Alzheimers Dis 42, 723-737.

[134] Singhrao SK, Harding A, Poole S, Kesavalu L, Crean S (2015) Porphyromonas gingivalis periodontal infection and its putative links with Alzheimer's disease. Mediators Inflamm 1015, 137357 doi: $10.1155 / 2015 / 137357$.

[135] Cambell LA, Rosenfeld ME (2015) Infection and atherosclerosis development. Arch Med Res 46(5), 339350 .

[136] Akiyama H, Barger S, Barnum S, Bradt B, Bauer J, Cole GM, Cooper NR, Eikelenboom P, Emmerling M, Fiebich BL, Finch CE, Frautschy S, Griffin WS, Hampel H, Hull M, Landreth G, Lue L, Mrak R, Mackenzie IR, McGeer PL, O’Banion MK, Pachter J, Pasinetti G, Plata-Salaman C, Rogers J, Rydel R, Shen Y, Streit W, Strohmeyer R, Tooyoma I, Van Muiswinkel FL, Veerhuis R, Walker D, Webster S, Wegrzyniak B, Wenk G, Wyss-Coray T (2000) Inflammation and Alzheimer’s disease. Neurobiol Aging 21, 383-421.

[137] Desvarieux M, Schwahn C, Volzke H, Demmer RT, Ludemann J, Kessler C, Jacobs DR, John U, Kocher $\mathrm{T}$ (2004) Gender differences in the relationship between periodontal disease, tooth loss and atherosclerosis. Stroke 35, 2029-2035.

[138] Jagannathachary S, Kamaraj D (2010) Obesity and periodontal disease. J Indian Soc Periodontol 14, 96100.

[139] Neto JBC, Rosa EF, Pannuti CM, Romito GA (2012) Smoking and periodontal disease: A review. Braz Oral Res 26,25-31.

[140] Kornman KS, Crane A, Wang HY, di Giovine FS, Newman MG, Pirk FW, Wilson TG Jr, Higginbottom FL, Duff GW (1997) The interleukin-1 genotype as a severity factor in adult periodontal disease. J Clin Periodontol 24, 72-77.

[141] Galbraith GMP, Hendley TM, Sanders JJ, PaleschY, Pandey JP (1999) Polymorphic cytokine genotypes as markers of disease severity in adult periodontitis. J Clin Periodontol 26, 705-709.

[142] Shao MY, Huang P, Cheng R, Hu T (2009) Interleukin-6 polymorphisms modify the risk of periodontitis: A systematic review and meta-analysis. J Zheijang Univ Sci B 10, 920-927.

[143] Kubota T, Maruyama S, Abe D, Tomita T, Morozumi T, Nakasone N, Saku T, Yoshie H (2014) Amyloid beta (A4) precursor protein expression in human periodontitis-affected gingival tissues. Arch Oral Biol 59, 586594.

[144] Nicoll JAR, Mrak RE, Graham DI, Stewart J, Wilcock G, MacGowan S, Esiri MM, Murray LS, Dewar D, Love S, Moss T, Griffin WS (2000) Association of interleukin-1 gene polymorphisms with Alzheimer's disease. Ann Neurol 47, 365-368.

[145] McGeer PL, McGeer EG (2001) Polymorphisms in inflammatory genes and the risk of Alzheimer disease. Arch Neurol 58, 1790-1792. 
[146] Harold D, Abraham R, Hollingworth P, Sims R, Gerrish A, HamshereML,Pahwa JS, MoskvinaV,Dowzell K,Williams A, Jones N, Thomas C, Stretton A, Morgan AR, Lovestone S, Powell J, Proitsi P, Lupton MK, Brayne C, Rubinsztein DC, Gill M, Lawlor B, Lynch A, Morgan K, Brown KS, Passmore PA, Craig D, McGuinness B, Todd S, Holmes C, Mann D, Smith AD, Love S, Kehoe PG, Hardy J, Mead S, Fox N, Rossor M, Collinge J, MaierW, Jessen F, Schurmann B, Heun R, van den Bussche H, Heuser I, Kornhuber J, Wiltfang J, Dichgans M, Fr"olich L, Hampel H, H“ull M, Rujescu D, Goate AM, Kauwe JS, Cruchaga C, Nowotny P, Morris JC, Mayo K, Sleegers K, Bettens K, Engelborghs S, De Deyn PP, Van Broeckhoven C, Livingston G, Bass NJ, Gurling H, McQuillin A, Gwilliam R, Deloukas P, Al-Chalabi A, Shaw CE, Tsolaki M, Singleton AB, Guerreiro R, M“uhleisen TW, N“othen MM, Moebus S, J“ockel KH, Klopp N, Wichmann HE, Carrasquillo MM, Pankratz VS, Younkin SG, Holmans PA, O’Donovan M, Owen MJ, Williams J (2009) Genome-wide association study identifies variants at CLU and PICALM associated with Alzheimer's disease. Nat Genet 41, 1088-1093.

[147] Lambert JC, Heath S, Even G, Campion D, Sleegers K, Hiltunen M, Combarros O, Zelenika D, Bullido MJ, Tavernier B, Letenneur L, Bettens K, Berr C, Pasquier F, Fi'evet N, Barberger-Gateau P, Engelborghs S, De Deyn P, Mateo I, Franck A, Helisalmi S, Porcellini E, Hanon O; European Alzheimer's Disease Initiative Investigators, de Pancorbo MM, Lendon C, Dufouil C, Jaillard C, Leveillard T, Alvarez V, Bosco P, Mancuso M, Panza F, Nacmias B, Boss `u P, Piccardi P, Annoni G, Seripa D, Galimberti D, Hannequin D, Licastro F, Soininen H, Ritchie K, Blanch'e H, Dartigues JF, Tzourio C, Gut I, Van Broeckhoven C, Alp’erovitch A, Lathrop M, Amouyel P (2009) Genome-wide association study identifies variants at CLU and CR1 associated with Alzheimer's disease. Nat Genet 41, 1094-1099.

[148] Corrada MM, Paganini-Hill A, Berlau DJ, Kawas CH (2013) Apolipoprotein E genotype, dementia, and mortality in the oldest old: the 90+ Study. Alzheimers Dement 9, 12-18.

[149] Mahley RW, Huang Y (2012) Small-molecule structure correctors target abnormal protein structure and function: structure corrector rescue of apolipoprotein E4 associated neuropathology. J Med Chem 55(21), 89979008. 